\title{
Production and physiological responses of heat-stressed lactating dairy cattle to conductive cooling
}

\author{
Kristen M. Perano, ${ }^{1}$ Joseph G. Usack, Largus T. Angenent, and Kifle G. Gebremedhin \\ Department of Biological and Environmental Engineering, Cornell University, Ithaca, NY 14853
}

\begin{abstract}
The objective of this research was to test the effectiveness of conductive cooling in alleviating heat stress of lactating dairy cows. A conductive cooling system was built with waterbeds (Dual Chamber Cow Waterbeds, Advanced Comfort Technology Inc., Reedsburg, WI) modified to circulate chilled water. The experiment lasted 7 wk. Eight first-lactation Holstein cows producing $34.4 \pm 3.7 \mathrm{~kg} / \mathrm{d}$ of milk at $166 \pm 28 \mathrm{~d}$ in milk were used in the study. Milk yield, dry matter intake (DMI), and rectal temperature were recorded twice daily, and respiration rate was recorded 5 times per day. During wk 1 , the cows were not exposed to experimental heat stress or conductive cooling. For the remaining $6 \mathrm{wk}$, the cows were exposed to heat stress from 0900 to 1700 $\mathrm{h}$ each day. During these $6 \mathrm{wk}, 4$ of the 8 cows were cooled with conductive cooling (experimental cows), and the other 4 were not cooled (control cows). The study consisted of 2 thermal environment exposures (temperature-humidity index mean \pm standard deviation of $80.7 \pm 0.9$ and $79.0 \pm 1.0)$ and 2 cooling water temperatures (circulating water through the water mattresses at temperatures of $4.5^{\circ} \mathrm{C}$ and $10^{\circ} \mathrm{C}$ ). Thus, a total of 4 conductive cooling treatments were tested, with each treatment lasting $1 \mathrm{wk}$. During wk 6 , the experimental and control cows were switched and the temperature-humidity index of $79.0 \pm 1.0$ with $4.5^{\circ} \mathrm{C}$ cooling water treatment was repeated. During wk 7 , waterbeds were placed directly on concrete stalls without actively cooling the water. Least squares means and $P$-values for the different treatments were calculated with multivariate mixed models. Conductively cooling the cows with $4.5^{\circ} \mathrm{C}$ water decreased rectal temperature by $1.0^{\circ} \mathrm{C}$, decreased respiration rate by 18 breaths/ min, increased milk yield by $5 \%$, and increased DMI by $14 \%$ compared with the controls. When the results from the 2 cooling water temperatures $\left(4.5^{\circ} \mathrm{C}\right.$ and $10^{\circ} \mathrm{C}$ circulating water) were compared, we found that the rectal temperature from $4.5^{\circ} \mathrm{C}$ cooling water was $0.3^{\circ} \mathrm{C}$
\end{abstract}

Received August 25, 2014.

Accepted April 23, 2015.

${ }^{1}$ Corresponding author: kmp263@cornell.edu lower than the rectal temperature with $10^{\circ} \mathrm{C}$ cooling water, but the other measurements (respiration rate, milk production, and DMI) did not show a statistically significant difference between the cooling water temperatures. Placing waterbeds on concrete stalls without additional cooling did not have a measurable effect in alleviating the heat stress of the cows.

Key words: heat stress, conductive cooling, waterbed, production response, physiological response

\section{INTRODUCTION}

Heat stress occurs when cows are exposed to ambient conditions of high heat, high humidity, or both, resulting in problems with disposing of excess metabolic heat. A cow may start to show signs of heat stress beginning at a temperature-humidity index (THI) of around 68 (Zimbelman et al., 2009). When a cow is heat stressed, her rectal temperature (Tre) and respiration rate (RR) will increase, and she will usually spend less time lying down (Cook et al., 2007). Dry matter intake and milk yield will decrease, and reproductive performance as well as immune function may decrease (Liu et al., 2014). Cows at any production level will show an inverse relationship between milk yield and heat stress (Ravagnolo et al., 2000; West, 2003). Higher-producing cows are more affected by heat stress than lower-producing cows because a higher milk yield requires a higher DMI and thus generates more metabolic heat (West et al., 2003). Heat stress costs the US dairy industry - a $\$ 40$ billion industry in 2013 (USDA, 2014) —an estimated 4 to $7 \%$ revenue loss per year (St-Pierre et al., 2003; USDA, 2006).

Lingering physiological effects of heat stress may cause economic losses that exceed those encountered during the actual heat stress event. The decrease in milk yield is partly due to endocrine changes, not just the immediate effects of having less available energy when DMI decreases (Rhoads et al., 2010). In many cases, cows do not return to their level of milk yield before the heat stress event, and under severe heat stress, cows may abort a pregnancy or even die (Stull et al., 2008; Norman et al., 2012). Climate change could exacerbate these losses by making the climate warmer 
or more variable (Crescio et al., 2010). Heat-stress episodes caused by variable climate can be especially challenging for cows to cope with because it may take weeks for a cow to fully adapt to heat-stress conditions (Cook et al., 2007).

Current practices for heat-stress relief include the provision of shade and various sprinkler, mister, and fan systems. Under hot and humid conditions, shades and fans alone are insufficient to alleviate heat stress. Mister systems use fine water molecules to cool the air, and thus are more effective in arid climates but less effective in high humidity conditions (Armstrong, 1994). Collier et al. (2006) reported that sprinkling cows can be effective even in high humidity conditions, but excess moisture from sprinkler systems may lead to hygiene problems and increased risk of disease (Stull et al., 2008). Furthermore, fans consume electricity and sprinkler or mister systems consume water. For example, a sprinkler system tested by Frazzi et al. (2002) consumed on average 15,500 L/cow per 120-d cooling season.

Most US dairies with 500 or more cows use sprinklers or misters to mitigate heat stress (USDA, 2010). The resulting high water consumption is especially a problem in the western United States, where water can be scarce. Systems requiring considerable energy consumption also rely on currently inexpensive electrical energy, but energy prices may rise in the future (Collier et al., 2006). Although air conditioning has been tested as a cooling mechanism, it is not an economically feasible option (Hahn et al., 1969). Conductive cooling systems have the potential to conserve water, be more hygienic than evaporation-based cooling systems, and provide more effective heat stress relief than fan-only systems. The pioneering study by Bastian et al. (2003) on conductive cooling demonstrated that a waterbed filled with continuously cooled water may be an effective way to relieve heat stress in dairy cows.

Concurrently with this study, Ortiz et al. (2015) evaluated the effectiveness of conductive cooling of lactating dairy cows under controlled environmental conditions (hot and dry, hot and humid, and thermoneutral). Heat exchangers with running water at $7^{\circ} \mathrm{C}$ were buried $25 \mathrm{~cm}$ below the stall surface to remove metabolic heat from the cows. Ortiz et al. (2015) used sand and dried manure as the bedding material in their conductive cooling system. They reported that use of the heat exchangers did not decrease $\mathrm{RR}$ or increase feed intake for either bedding type. However, for sand bedding, the Tre of the cooled cows was reduced under both of the heat-stress conditions. Milk yield increased for the cooled cows under hot and humid conditions but was not significantly different between cooled and control cows for the hot and dry conditions. For the dried manure bedding, the use of conductive cooling did not affect milk yield and only lowered Tre under hot and humid conditions. The highest measured heat flux from the cow to the stall surface was $28.65 \mathrm{~W} / \mathrm{m}^{2}$ for a hot and humid environment with sand bedding and the heat exchanger on. This small heat transfer was attributed to the deep bedding $(25 \mathrm{~cm})$ used in the study to keep the cows comfortable and protect the heat exchanger (Ortiz et al., 2015). The study concluded that more work is needed to increase the efficiency of conductive cooling.

The use of cooled waterbeds in stalls has the advantage of providing cushioning for the cow and allowing almost direct contact between the skin surface and the cooled waterbed surface and thus allowing substantial heat flow. The objective of this research was to assess the effectiveness of a conductive cooling system using continuously cooled waterbeds to alleviate heat stress of high-producing, lactating dairy cattle.

\section{MATERIALS AND METHODS}

The experiment was conducted in the Large Animal Research and Teaching Unit (LARTU) at Cornell University using 8 primiparous Holstein cows that produced $34.4 \pm 3.7 \mathrm{~kg} / \mathrm{d}$ of milk at $166 \pm 28 \mathrm{~d}$ in milk (mean $\pm \mathrm{SD}$ ). Cows were confirmed pregnant before the start of the study. Two identical climate-controlled rooms with tiestalls housed 4 cows each. The conductive cooling system used DCC waterbeds (Dual Chamber Cow Waterbeds, Advanced Comfort Technologies Inc., Reedsburg, WI), with some modifications as described in the Cooling System Design section. The experimental protocol and students involved in the study were approved by the Institutional Animal Care and Use Committee (IACUC) at Cornell University.

The cows were milked twice daily at 0600 and $1800 \mathrm{~h}$, and milk weights were recorded at each milking. Before the morning milking, the cows were moved into the climate-controlled rooms at $0530 \mathrm{~h}$. Experimental heat stress was imposed from 0900 to $1700 \mathrm{~h}$, and all cows stayed in waterbed stalls during the daytime. Two identical, adjacent, climate-controlled rooms were used in this study. In each room, 2 experimental (conductively cooled) cows were housed on one side of the room and 2 control (not cooled) cows were housed on the other side of the room. All cows faced in the same direction. At $1900 \mathrm{~h}$ after evening milking, the cows were placed individually and left loose in a night pen so that they could exercise. All the night pens were in a large and well-ventilated room.

All the cows were fed a wet (moisture content 58\% wet basis) TMR formulated for primiparous, mid-lactation Holsteins (Table 1). Fresh feed was mixed daily 
Table 1. Composition, chemical analysis, and nutritive value of TMR fed to the cows during the study ${ }^{1,2}$

\begin{tabular}{lc}
\hline Item & \% of DM \\
\hline Ingredient $^{3}$ & \\
Brown mid-rib corn silage $^{4}$ Concentrate mixture $^{4}$ & 30.7 \\
Corn meal $_{\text {Conventional corn silage }}$ & 20.6 \\
Hay crop silage & 18 \\
Canola meal $_{\text {Bypass fat }}^{5}$ & 13.1 \\
Calculated composition & 10.9 \\
Adjusted protein & 5.5 \\
Adjusted total starch & \\
NDF & 1.2 \\
Fat & \\
Ca & 15.4 \\
P & 26.6 \\
K & 31 \\
Na & 4.4 \\
\hline
\end{tabular}

${ }^{1}$ Diet DM averaged $42 \%$, and $\mathrm{NE}_{\mathrm{M}}$ was $1.63 \mathrm{Mcal} / \mathrm{kg}$ of DM.

${ }^{2}$ Monensin was added at the rate of $0.0126 \mathrm{~g} / \mathrm{kg}$.

${ }^{3}$ Cows were also given ad libitum access to trace mineralized salt licks. ${ }^{4}$ Concentrate mixture contained $25.0 \%$ corn germ meal, $19.5 \%$ citrus pulp, $15.3 \%$ distillers grains, $11.3 \%$ soybean hulls, $8.9 \%$ chocolate dairy mix, $5.9 \%$ blood meal, $5.7 \%$ calcium carbonate, $3.9 \%$ sodium bicarbonate, and other supplements for minerals and amino acids.

${ }^{5}$ Energy Booster 100 Fat Supplement (Hubbard Feeds, Mankato, MN).

${ }^{6}$ Crude protein adjusted based on bound protein determined by acid detergent insoluble $\mathrm{N}$ analysis.

${ }^{7}$ Starch value determined by a starch assay with amylase, after adjusting for base sugar levels.

and made available to the cows at $1200 \mathrm{~h}$. The cows had ad libitum access to water and to the TMR at all times as well as to timothy grass hay through the night. Daily feed refusals from both daytime and nighttime feed bins were weighed at $0900 \mathrm{~h}$ for each individual cow. Milk yield and feed intake were measured using certified scales.

\section{Cooling System Design}

Cool water was circulated through the modified waterbeds. All 8 stalls were installed with waterbeds, which were $1.83 \mathrm{~m}$ long and $1.17 \mathrm{~m}$ wide (Figure 1). The noncooled waterbeds were filled with $53 \mathrm{~L}$ of water as per the manufacturer's recommendations. The 4 cooled waterbeds were modified for water circulation by installing bulkhead fittings underneath the bed on diagonally opposite corners and inserting spacers in the restricted flow channels. The waterbed outlets were pressurized with $0.54 \mathrm{~m}$ of head to maintain a pressure and volume comparable to that of a noncooled waterbed with a cow lying on it. Approximately $1 \mathrm{~cm}$ of sawdust bedding was sprinkled on top of each waterbed and replaced several times a day whenever the bedding became soiled. All waterbeds (i.e., cooled and noncooled) were placed on a sheet of 1.9-cm-thick plywood on top of insulation $(\mathrm{R}=$

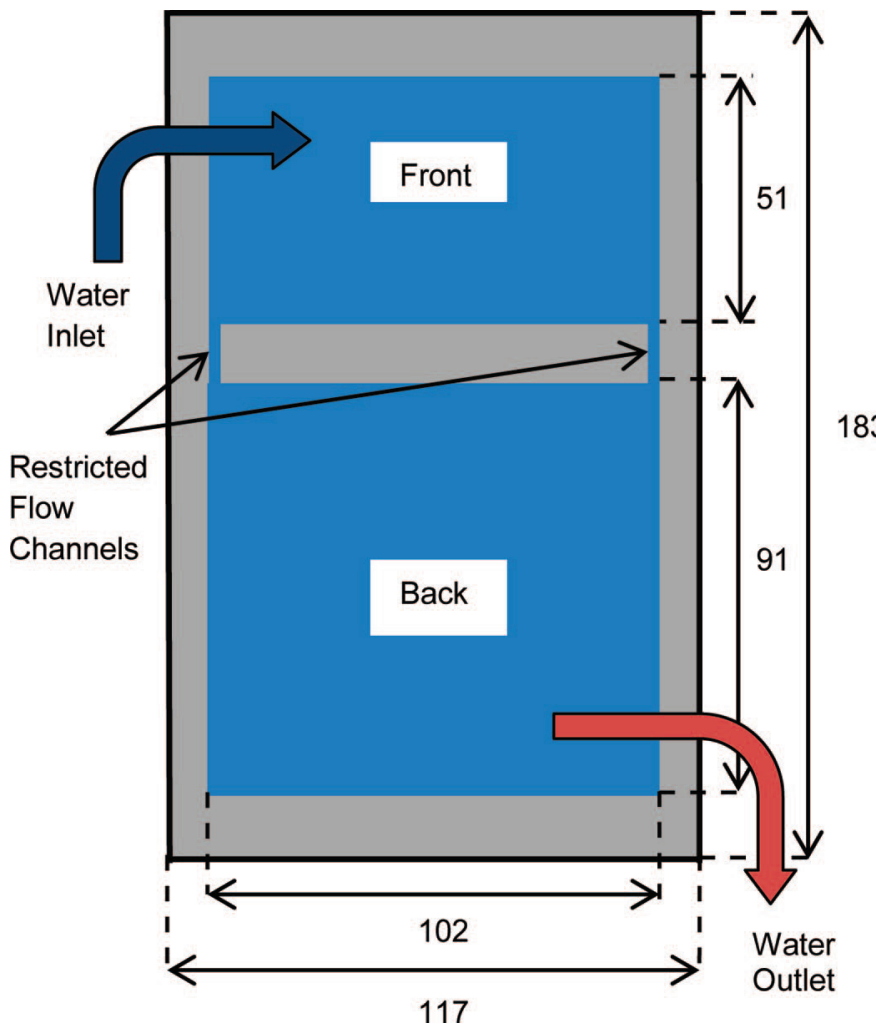

Figure 1. Dimensions $(\mathrm{cm})$ of waterbeds. Spacers were inserted in the restricted flow channels to allow water to circulate through the beds. Color version available online.

1.76 $\mathrm{K} \cdot \mathrm{m}^{2} / \mathrm{W}$ ) and individually secured in the concrete stalls. During the last week of the study, the insulation beneath the 4 noncooled waterbeds was removed to determine if there was measurable cooling from heat loss through the concrete floor when cows were lying down on the waterbeds.

The flow rate through the cooled waterbeds was measured with a turbine flow rate sensor (FT-110, Gems Sensors, Plainville, CT), and the inlet and outlet water temperatures were recorded with thermocouples (Type $\mathrm{T}, \mathrm{PVC}$ insulated). The thermocouples were inserted directly into the pump inlet filter and the water outlet flow stream, respectively (Figure 2). Flow rates and inlet and outlet water temperatures were recorded every 2 min with a data logger (CR1000, Campbell Scientific, Logan, UT). The 2 cooled waterbeds in each room shared a 160-L-capacity reservoir, where the water was chilled to maintain the desired water temperature. Cool water was pumped through each bed at a rate of 0.17 $\mathrm{L} / \mathrm{s}$ so that water circulating through the bed would heat up no more than 1 to $2^{\circ} \mathrm{C}$. The temperature and humidity of the 2 climate-controlled rooms and the night pen were recorded with Hobo Pro v2 data loggers (model U23-001, Onset Computer Corp., Bourne, MA). A data logger was suspended at each side of the 


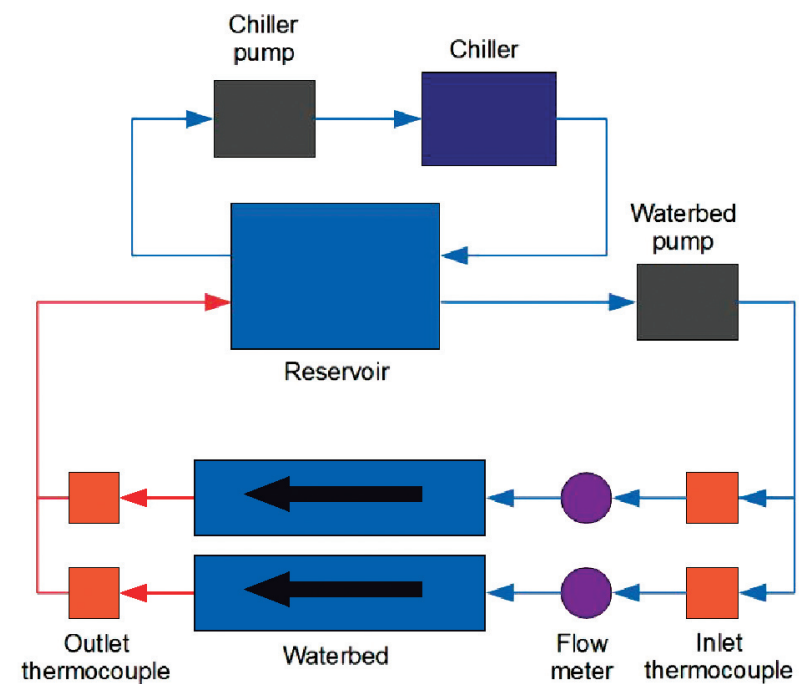

Figure 2. Schematic of the conductive cooling system. Waterbeds were modified with valves to allow water circulation. Color version available online.

climate-controlled rooms on a scaffold about $2.5 \mathrm{~m}$ above the floor, and 3 data loggers were placed in the night pen room.

\section{Experimental Design}

During wk 1, baseline physiological and production data were collected with the cows in the facility but with no conductive cooling and no experimental heat stress applied to any of the cows. Next, the conductive cooling system was tested at 2 different daytime thermal environments, a lower average THI of 79.0 \pm 1.0 (thermal environment 1) and a higher average THI of $80.7 \pm 0.9$ (thermal environment 2). Thermal environments were significantly different for THI values and were chosen after consultation with the IACUC veterinarians overseeing the research. The system was also tested at 2 cooling water temperatures $\left(4.5^{\circ} \mathrm{C}\right.$ and $10^{\circ} \mathrm{C}$ circulating cooling water). Two cooling water temperatures were chosen because $4.5^{\circ} \mathrm{C}$ cooling water will generate a greater temperature gradient and thus remove more heat from the cow, but cooling water to $10^{\circ} \mathrm{C}$ is more thermodynamically efficient. For wk 2 through wk 5 of the experiment, the 4 combinations of thermal environment and cooling temperature were tested for $1 \mathrm{wk}$ each. The control and experimental cows were then switched and the treatment with THI of 79.0 and $4.5^{\circ} \mathrm{C}$ cooling water was repeated. For the final treatment during wk 7 , the waterbeds for 2 of the experimental and 2 of the control cows were placed directly in the concrete stall with no additional cooling. Each treatment lasted $7 \mathrm{~d}$, and the entire experimental period lasted $49 \mathrm{~d}$ (Table 2).

The THI was calculated from the equation used by Dikmen and Hansen (2009):

$$
\begin{gathered}
\mathrm{THI}=(1.8 \times \mathrm{db}+32)-[(0.55-0.0055 \times \% \mathrm{RH}) \\
\times(1.8 \times \mathrm{db}-26.8)],
\end{gathered}
$$

where db is dry bulb temperature in ${ }^{\circ} \mathrm{C}$ and $\% \mathrm{RH}$ is relative humidity.

Rectal temperature and RR were recorded at $0730 \mathrm{~h}$ before heat stress was imposed on the cows and again at $1700 \mathrm{~h}$, which was after about $8 \mathrm{~h}$ of heat-stress exposure (Figure 3 ). In addition, respiration rates were measured at 1000, 1230, and $1445 \mathrm{~h}$, which gives a total of 5 measurements per day. Rectal temperatures were taken with a digital livestock thermometer (dual-scale digital thermometer, VetOne, Boise, ID; precision and accuracy $\left.=0.1^{\circ} \mathrm{C}\right)$. Respiration rates in breaths $/ \mathrm{min}$

\begin{tabular}{|c|c|c|c|c|c|}
\hline Treatment & $\begin{array}{l}\text { Thermal } \\
\text { environment }^{1}\end{array}$ & $\begin{array}{c}\text { Daytime } \\
\text { THI }^{2,3}\end{array}$ & $\underset{\text { THI }^{4}}{\text { Nighttime }}$ & $\begin{array}{l}\text { Cooling } \\
\text { level }^{5}\end{array}$ & Designation \\
\hline 1 & Baseline & $72.8 \pm 0.4$ & $73.6 \pm 2.4$ & None & Baseline/no cooling and no applied heat stress \\
\hline 2 & 2 & $80.5 \pm 0.7$ & $76.7 \pm 1.2$ & $10^{\circ} \mathrm{C}$ & Group 1 control and group 2 cooled \\
\hline 4 & 1 & $79.5 \pm 0.4$ & $75.2 \pm 2.6$ & $4.5^{\circ} \mathrm{C}$ & Group 1 control and group 2 cooled \\
\hline 5 & 1 & $79.0 \pm 0.7$ & $69.6 \pm 2.0$ & $10^{\circ} \mathrm{C}$ & Group 1 control and group 2 cooled \\
\hline 6 & 1 & $79.1 \pm 1.0$ & $69.4 \pm 2.2$ & $4.5^{\circ} \mathrm{C}$ & Switch group 1 and group 2 \\
\hline
\end{tabular}

Table 2. Experimental design: all cows were included in the baseline treatment; group 1 and group 2 each consisted of 4 randomly assigned cows

${ }^{1}$ Average temperature $\left({ }^{\circ} \mathrm{C}\right.$ ) and humidity (\% relative humidity) were $23.3 \pm 0.2$ and $86.5 \pm 2.3$ for baseline thermal environment, and $29.6 \pm 0.3$ and $57.1 \pm 4.9$ for thermal environment 1 , and $30.6 \pm 0.7$ and $59.7 \pm 2.4$ for thermal environment 2 .

${ }^{2}$ Temperature-humidity $(\mathrm{THI})$ equation: THI $=(1.8 \times \mathrm{db}+32)-[(0.55-0.0055 \times \% \mathrm{RH}) \times(1.8 \times \mathrm{db}-26.8)]$, where db is dry bulb temperature $\left({ }^{\circ} \mathrm{C}\right)$ and $\% \mathrm{RH}$ is relative humidity.

${ }^{3}$ Average daily THI for 1200 to $1700 \mathrm{~h}$.

${ }^{4}$ Nighttime: $2000 \mathrm{~h}$ of the previous night to $0530 \mathrm{~h}$.

${ }^{5} \mathrm{None}=$ no water circulation, and $10^{\circ} \mathrm{C}$ or $4.5^{\circ} \mathrm{C}$ designates the temperature of the water circulating through the waterbeds.

${ }^{6}$ Two cows each from groups 1 and 2 were randomly assigned to the waterbeds on the concrete treatment. 


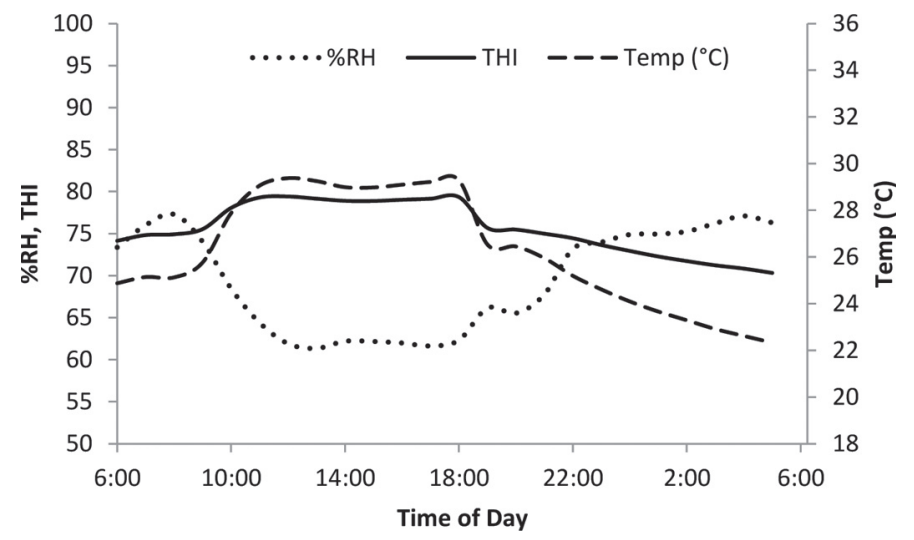

Figure 3. Temperature-humidity index (THI), relative humidity $(\% \mathrm{RH})$, and dry bulb air temperature $\left({ }^{\circ} \mathrm{C}\right)$ experienced by the cows for a typical day for thermal environment 1 (the lower heat-stress treatment). The cows were moved into the climate-controlled rooms at 0530 $\mathrm{h}$ and moved out at $1830 \mathrm{~h}$.

(bpm) were determined by visual inspection of flank movement for $30 \mathrm{~s}$.

\section{Sprinklers for Flow Rate Measurements}

To better characterize the water usage offset by the conductive cooling system, a sprinkler system was built using components typical for dairy sprinkler systems in the northeastern United States. The sprinkler system was then tested for how much water it consumed while operating under comparable climactic conditions to the conductive cooling system. The sprinkler line was built with $6.4 \mathrm{~m}$ of 2.54-cm-diameter PVC pipe and 4 sprinkler nozzles (yellow misting nozzle, Farmer Boy Ag, Myerstown, PA). Fans (20-inch box fan, Lasko, West Chester, PA) were installed above each stall about $2.5 \mathrm{~m}$ above the floor and used on high speed (85 $\mathrm{W})$. Sprinklers and fans were angled at $30^{\circ}$ from the horizontal. Sprinkler output was $810 \pm 12 \mathrm{~g} / \mathrm{min}$ per nozzle. Time required to wet the cow and the wetting interval were determined by visual inspection.

\section{Data Analysis}

Mixed linear models were fitted using the software package JMP (SAS Institute Inc., Cary, NC) for the production and physiological responses (Tre, RR, milk yield, and DMI). Average Tre was modeled at 1700 $\mathrm{h}$, and RR was modeled as the daily average for the 4 measurements taken under heat stress $(1000,1230$, 1445, and $1700 \mathrm{~h}$ ). Average daily milk yield and DMI were modeled as proportion decline from the baseline. Models for all 4 responses included the random effects of variations between cows (Cow ID) and Cow ID nested within treatment as well as the fixed effect of cooling level (control/no cooling, $10^{\circ} \mathrm{C}$ circulating water, and $4.5^{\circ} \mathrm{C}$ circulating water) and the fixed effect of thermal environment (thermal environment 1 with average THI of 79.0 or thermal environment 2 with average THI of 80.7; see Table 2 for experimental design). The cooling level $\times$ thermal environment interaction was tested for each model but was not significant. Thus, this term was removed from all of the models for the main analysis but was used to calculate the responses for each combination of THI and cooling water temperature shown in Appendix Table A1. All models used a standard residuals structure to estimate the least squares means (LSM) for each treatment; $P$-values were obtained from Tukey-Kramer Honestly Significant Difference (HSD) tests.

For Tre and RR, data from all $7 \mathrm{~d}$ of each treatment were used in the analysis. In addition to the fixed effects of thermal environment and cooling level, the model for Tre included the fixed effects of the daily morning Tre and the average baseline Tre at $1700 \mathrm{~h}$ as linear co-variants. The pre-heat-stress morning measurements for Tre were included to help account for variation in nighttime environment, and the baseline afternoon Tre for each cow was included to account for individual variations between cows. The model for $\mathrm{RR}$ was constructed in the same way as the Tre model but replacing evening measurements with daily averages during heat-stress exposure. For the milk yield and DMI models, only data from the last $4 \mathrm{~d}$ of each treatment were used in the model so that the cows could acclimate to the new treatment during the first 3 d. Declines in milk yield and DMI were calculated with respect to average milk yield and DMI from the last 4 $\mathrm{d}$ of the baseline treatment.

Crossover data compared the mean $\pm \mathrm{SD}$ from the sample data from treatment 4 to treatment 6 (see Table $2)$. Statistical $P$-values for the crossover were obtained from paired $t$-tests on all 8 cows. The RR dynamics shows the RR of the 4 cooled and the 4 control cows for both treatment 2 and treatment 3 (see Table 2) at each of the times the RR was measured. The $t$-tests were used to compare both cooling water temperatures to the control for each of the time points measured.

\section{RESULTS AND DISCUSSION}

\section{Effect of Conductive Cooling}

The fixed effect of cooling level (control/no cooling, $10^{\circ} \mathrm{C}$ circulating water, and $4.5^{\circ} \mathrm{C}$ circulating water) was significant for milk yield $(P=0.042$, see Table 3$)$ and for Tre, RR, and DMI $(P<0.001)$. The fixed effect of thermal environment was also statistically significant for all variables. However, the cooling level $\times$ thermal 
Table 3. Statistical significance of fixed effects in mixed models ${ }^{1,2}$

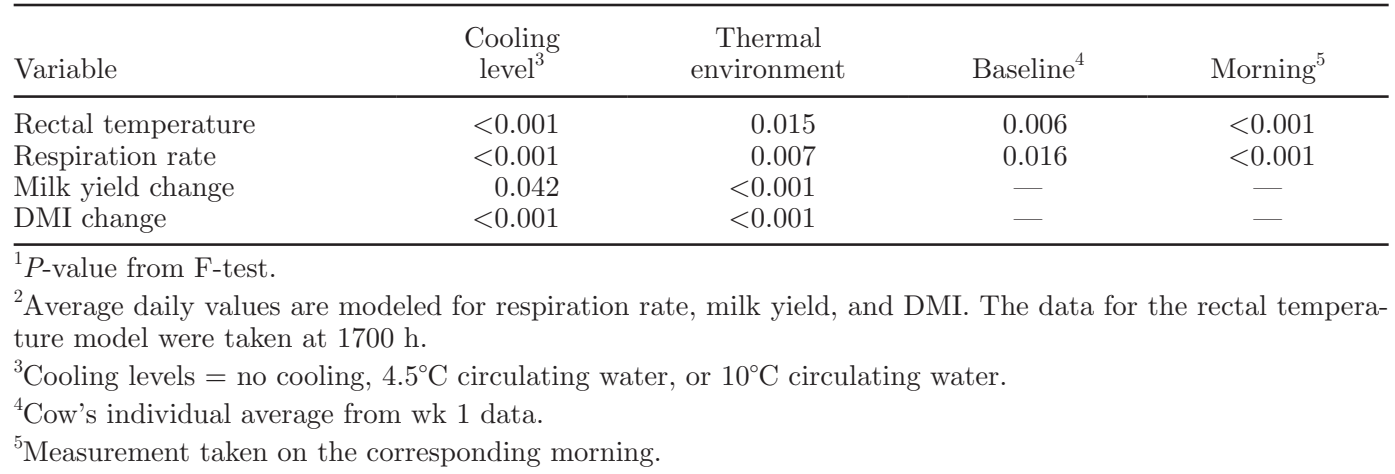

environment interaction was not statistically significant for any of the variables so was not used in the models. The fixed effects of the baseline data (the individual average of each cow from wk 1 data) and morning measurements were statistically significant for Tre and RR (Table 3).

Rectal temperature decreased $(P<0.001)$ by $0.7^{\circ} \mathrm{C}$ and $1.0^{\circ} \mathrm{C}$ for cows cooled with $10^{\circ} \mathrm{C}$ and $4.5^{\circ} \mathrm{C}$ circulating water, respectively, compared with controls (Figure 4). The difference of $0.3^{\circ} \mathrm{C}$ between the 2 cooling water temperatures was also significant $(P=0.015)$. Thermal environment also had a statistically significant effect on Tre with thermal environment 2 (THI $80.7 \pm 0.9$ ) increasing the Tre by $0.2^{\circ} \mathrm{C}(P=0.015)$ compared with thermal environment 1 (THI $79.0 \pm 1.0$ ). The Tre of $39.1 \pm 0.1^{\circ} \mathrm{C}$ for the cows conductively cooled with $4.5^{\circ} \mathrm{C}$ circulating water was in the normal physiological range of 38.0 to $39.3^{\circ} \mathrm{C}$ (Merck Veterinary Manual, 2012). Similarly, Spiers et al. (2004) reported rectal temperature of $39.0^{\circ} \mathrm{C}$ for cows in a thermoneutral environment (ambient temperature of 17.9 to $20.2^{\circ} \mathrm{C}$ ). Thus, conductive cooling reduced the Tre of the cows to levels comparable to Tre under thermoneutral conditions. Because elevated Tre is a reliable indicator of heat stress (Gebremedhin et al., 2008; Suthar et al., 2012), the statistically highly significant effect of conductive cooling on Tre shows that conductive cooling was effective at mitigating some of the heat stress.

Respiration rate decreased $(P<0.001)$ for cows at both cooling water temperatures compared with controls (Figure 5), but the difference in RR between the 2 cooling water temperatures was not significant. The $\mathrm{RR}$ was $82 \pm 2 \mathrm{bpm}$ for control cows (no cooling), 68 $\pm 2 \mathrm{bpm}$ when cows were cooled with $10^{\circ} \mathrm{C}$ circulating water, and $64 \pm 2 \mathrm{bpm}$ when cows were cooled with $4.5^{\circ} \mathrm{C}$ water. Notably, the RR for the $4.5^{\circ} \mathrm{C}$-cooled cows differed little from the RR of $60 \mathrm{bpm}$ reported by Spiers et al. (2004) for cows in a thermoneutral environment. This indicates that the conductively cooled cows effectively experienced minimal heat stress. The high RR observed in the control cows is a clear indicator of heat stress as cows respired more to dissipate excess heat. A high $\mathrm{RR}$ can also cause respiratory alkalosis from increased $\mathrm{CO}_{2}$ loss, which may lead to unhealthy fluctuations in blood pH (Cook et al., 2007). Respiration rate was also affected by thermal environment, with thermal environment 2 increasing RR by 4 bpm compared with thermal environment $1(P=0.007)$.

Milk yield declined across all treatments (Figure 6). Baseline milk production was $34.1 \pm 4.4 \mathrm{~kg} /$ cow per day at THI $=72.8 \pm 0.4$ with no significant differences in baseline production between the 2 groups before the start of the experimental heat stress. Declines from baseline production were $11.2 \%$ for cows in the control treatment, $5.5 \%$ when the cows were cooled with $10^{\circ} \mathrm{C}$ circulating water $(P=0.20$, compared with control), and $4.7 \%$ when the cows were cooled with $4.5^{\circ} \mathrm{C}$ water

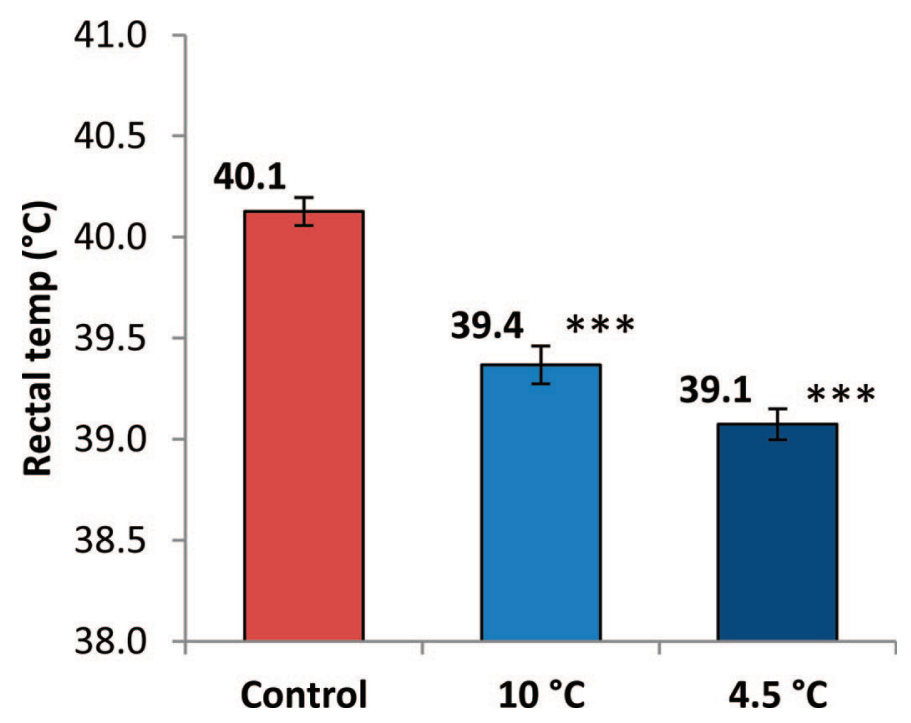

Figure 4. Least squares means $( \pm \mathrm{SE})$ for rectal temperature $\left({ }^{\circ} \mathrm{C}\right)$ for the control and the 2 cooling water temperatures. ${ }^{* * *} P<0.001$ compared with control (Tukey Honestly Significant Difference test). The difference in rectal temperature between the 2 cooling water temperatures was also significant $(P=0.015)$. Color version available online. 


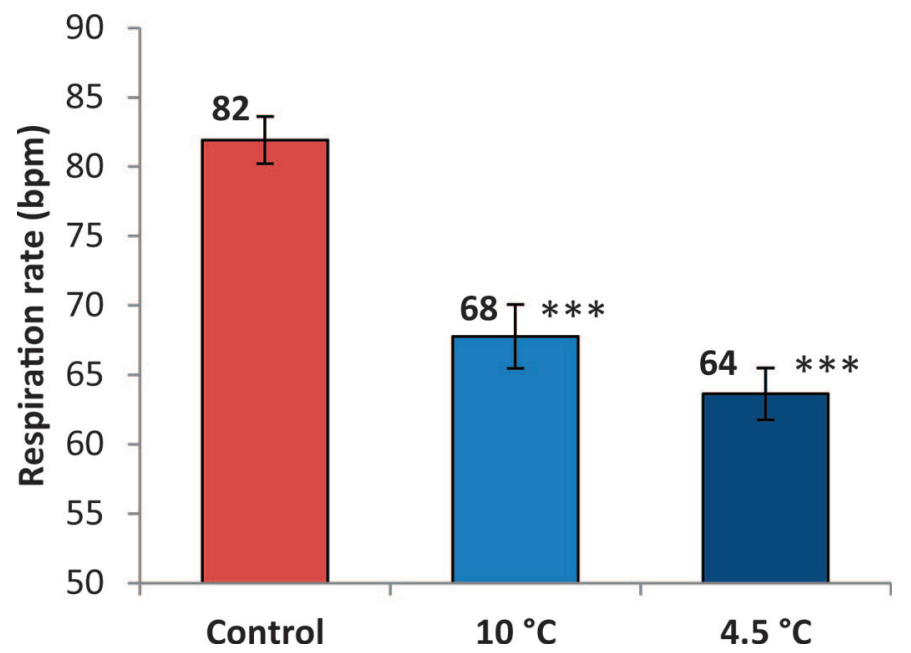

Figure 5. Least squares means $( \pm \mathrm{SE})$ for respiration rate (breaths/ min, bpm) for the control and the 2 cooling water temperatures. $* * * P$ $<0.001$ compared with control (Tukey Honestly Significant Difference test). Respiration rates were not significantly different between the 2 cooling water temperatures. Color version available online.

$(P=0.04$, compared with control). Differences in milk yield for cows cooled with $10^{\circ} \mathrm{C}$ versus $4.5^{\circ} \mathrm{C}$ water were not significant, but thermal environment did have a significant effect on milk yield. Milk yield decline from baseline was $8.0 \%$ less for thermal environment 1 than for thermal environment $2(P=<0.001)$.

Dry matter intake increased over the baseline consumption of $18.5 \pm 1.8 \mathrm{~kg} / \mathrm{cow}$ per day for all treatments (Figure 7). Differences in baseline DMI were not significant between the 2 groups before the start of the heat stress. After heat stress was imposed, DMI increase over baseline consumption was $3.3 \%$ for the control cows, $11.2 \%$ when the cows were cooled with $10^{\circ} \mathrm{C}$ circulating water $(P=0.09$, compared with control $)$, and $17.2 \%$ when the cows were cooled with $4.5^{\circ} \mathrm{C}$ water $(P$ $<0.001$, compared with control). However, differences in DMI between the 2 cooling water temperatures were not significant. Thermal environment also had an effect on DMI $(P<0.001)$. Cows increased DMI by $19.7 \%$ over baseline consumption when exposed to thermal environment 1, but the increase in DMI was only $1.4 \%$ over baseline when the cows were exposed to thermal environment 2.

Although the variables considered suggest that conductive cooling was effective in mitigating heat stress, milk yield decline was not statistically significant for the $10^{\circ} \mathrm{C}$ cooling water temperature (Figure 6). This was probably due to the small sample size and individual cow variations. Primiparous cows, such as the cows in this study, may also be less sensitive to heat stress than multiparous cows (Meyer et al., 2002; Bernabucci et al., 2014). Moreover, the cows were kept in well-ventilated pens at night, and during many of the nights the cows

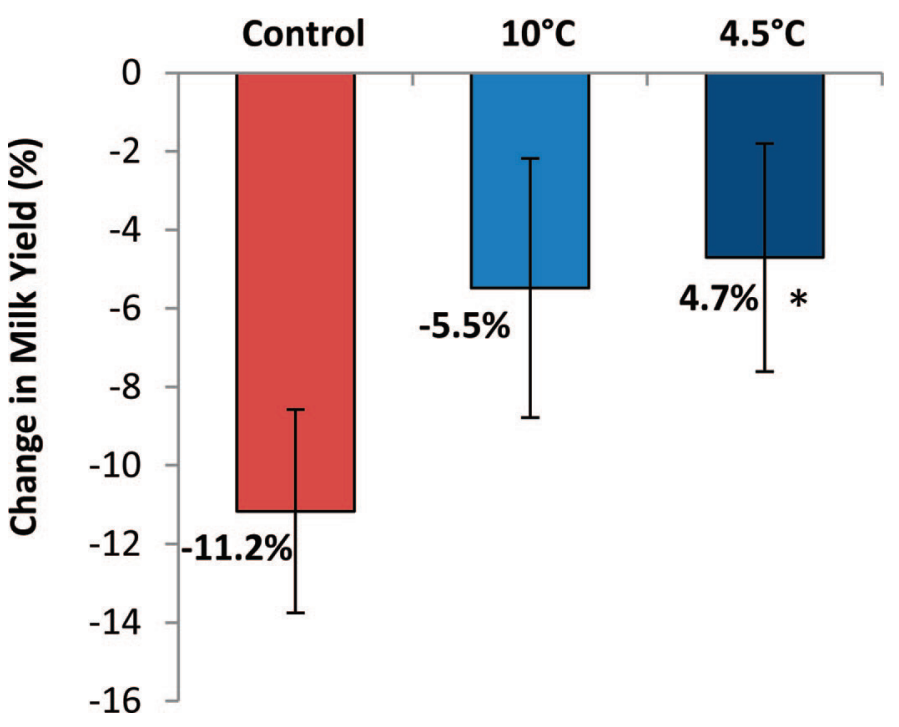

Figure 6. Least squares means $( \pm \mathrm{SE})$ for milk yield (percentage change) with respect to the baseline for the control and the 2 cooling water temperatures. ${ }^{*} P<0.05$ compared with control (Tukey Honestly Significant Difference test). The milk yield was not significantly different between the 2 cooling water temperatures. Color version available online.

were exposed to cooler conditions than what would typically follow a moderate or severe heat-stress day. Igono et al. (1987) reported that regaining normal body temperature overnight is a critical factor in maintaining milk production during heat stress. Thus, the cooler nighttime conditions in our study may have obscured

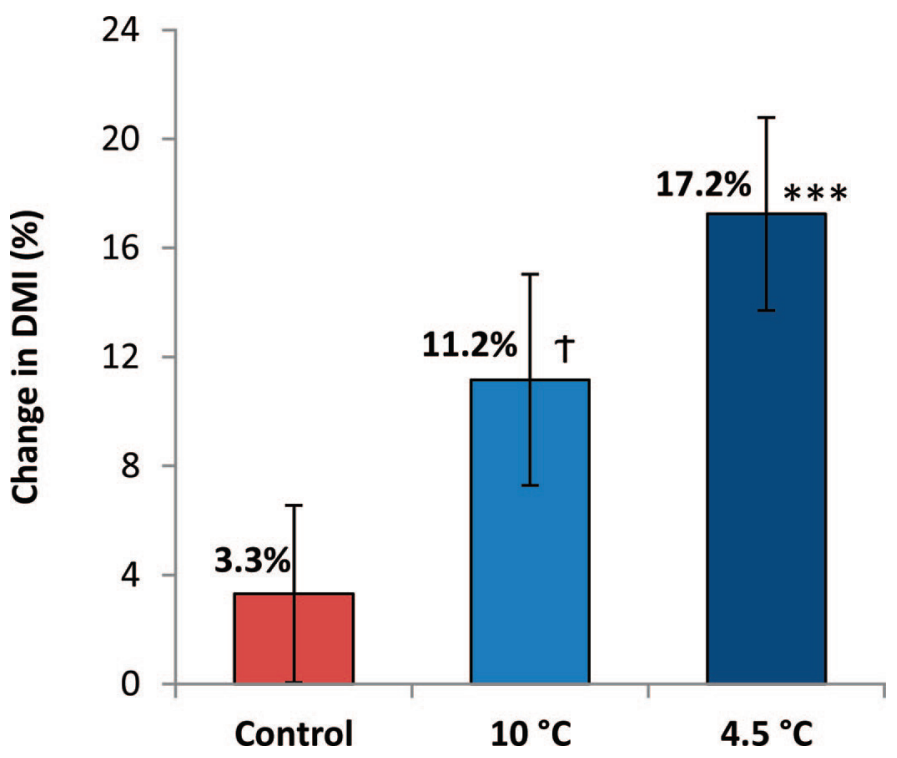

Figure 7. Least squares means $( \pm \mathrm{SE})$ for DMI (percentage change) from the baseline for the control and the 2 cooling water temperatures. $\dagger P<0.1$ and ${ }^{* * *} P<0.001$ compared with control (Tukey Honestly Significant Difference test). The difference in DMI between the 2 cooling water temperatures was not significant. Color version available online. 
the mitigating effect of the conductive cooling because the control cows were recovering overnight.

\section{Crossover}

Switching the control and conductively cooled cows further confirmed the repeatable effects of conductive cooling on reducing heat stress. Conductive cooling with $4.5^{\circ} \mathrm{C}$ circulating water had an effect on the evening Tre $(P<0.001)$, and the responses of the 2 randomly assigned groups of cows to the cooling water temperatures were fairly consistent. Group 1 cows (cows that were initially in the control group, see Table 2) averaged an evening Tre of $40.2 \pm 0.5^{\circ} \mathrm{C}$ when not cooled and $38.9 \pm 0.2^{\circ} \mathrm{C}$ when conductively cooled. Group 2 cows (cows that were initially cooled) averaged $40.1 \pm$ $0.4^{\circ} \mathrm{C}$ when not cooled and $39.0 \pm 0.5^{\circ} \mathrm{C}$ when cooled. A similar effect was evident in $\mathrm{RR}$, with cows showing lower RR when conductively cooled versus not cooled $(P=0.005)$. Group 1 cows averaged $79 \pm 10 \mathrm{bpm}$ (mean $\pm \mathrm{SD}$ ) when not cooled but $61 \pm 13 \mathrm{bpm}$ when conductively cooled; group 2 cows averaged $79 \pm 16$ and $64 \pm 6 \mathrm{bpm}$ for not cooled and cooled, respectively. Thus, switching the cows between treatments further confirmed the effectiveness of conductive cooling in alleviating heat stress.

\section{Respiration Rate Dynamics}

Respiration rate for cooled cows at thermal environment 2 (THI $80.7 \pm 0.9$ ) was fairly constant throughout the day, but for the control cows, RR increased significantly after heat stress was imposed (Figure 8). The lower $\mathrm{RR}$ at $0730 \mathrm{~h}$ with $4.5^{\circ} \mathrm{C}$ cooling may be due to the slightly lower nighttime THI during treatment 3 when the data were collected (Table 2). At $0730 \mathrm{~h}$, before experimental heat stress was imposed or conductive cooling started, there were no significant differences in average RR for the cows under the 2 cooling conditions and control. However, by 1000 h, after about $1 \mathrm{~h}$ of heat stress, the control cows had a higher RR than the cows cooled with either $10^{\circ} \mathrm{C}$ circulating water $(P=0.052)$ or $4.5^{\circ} \mathrm{C}$ water $(P=0.005)$. Average $\mathrm{RR}$ of the control cows as well as both groups of cooled cows remained consistent throughout the heat-stress exposure (Figure 8).

\section{Alternative Conductive Cooling Systems}

When the waterbeds were placed directly on a concrete surface, none of the variables measured showed any difference against the control (i.e., no circulating water and with insulation below the waterbeds, see Table 4). The manufacturer recommends installing

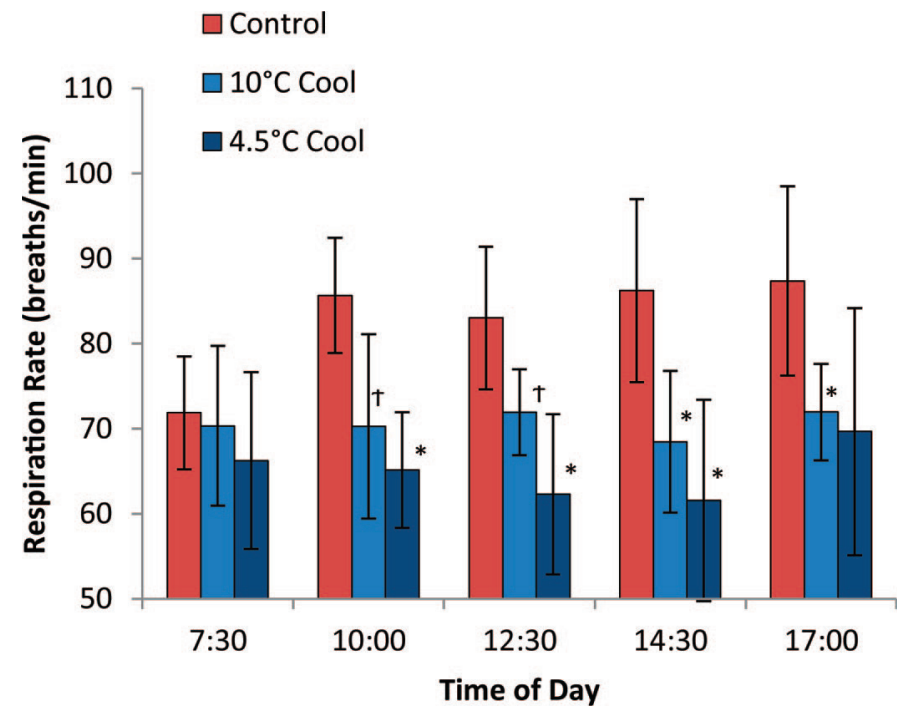

Figure 8. Average respiration rates (breaths/min) under thermal environment 2 for the 4 cows in the control (over 2 wk) versus the 4 cows under the 2 cooling water temperatures ( 1 week per cooling temperature). $\dagger P<0.1$ and $* P<0.05$ compared with control with a $t$-test. Differences in respiration rate between the 2 cooling water temperatures were not significant. Error bars are the SD of the variation between cows. Color version available online.

waterbeds on top of a concrete surface. The concrete surface temperature will be lower than the skin temperature of the cow, so heat will flow from the cow to the concrete surface when the cow is lying down on the waterbed. However, in this study, the cooling effect from the heat flow to the concrete surface was negligible because there was no measurable effect on the Tre, RR, milk yield, or DMI of the cows.

The system tested by Ortiz et al. (2015) used thick bedding $(25 \mathrm{~cm})$ between the cow and a flat-plate heat exchanger. Under hot and humid conditions comparable to those in our study, Ortiz et al. (2015) reported a statistically significant reduction in Tre of $0.13^{\circ} \mathrm{C}$ for sand bedding and $0.14^{\circ} \mathrm{C}$ for dried manure bedding using conductive cooling with a water temperature of $7^{\circ} \mathrm{C}$. However, our system had a stronger response in Tre to the conductive cooling. In our study, Tre was reduced by $1.0^{\circ} \mathrm{C}$ with $4.5^{\circ} \mathrm{C}$ cooling water and by $0.7^{\circ} \mathrm{C}$ with $10^{\circ} \mathrm{C}$ cooling water. Unlike the system used by Ortiz et al. (2015), our system used waterbeds as heat exchangers. This allows the cow to be in almost direct contact with the heat exchanger and eliminates thick bedding, which insulates between the cow and the heat exchanger.

\section{Water Usage in a Sprinkler System}

Time required to wet the hair coat to saturation over the cow's back and sides was approximately $1 \mathrm{~min}$, and the hair coat took approximately 15 min to dry. Thus, 
Table 4. Physiological and production responses for control cows versus cows with waterbeds directly placed on a concrete surface

\begin{tabular}{lcccc}
\hline Variable & Control $^{1}$ & Concrete $^{2}$ & SE & $P$-value \\
\hline Rectal temperature $\left({ }^{\circ} \mathrm{C}\right)$ & 40.1 & 40.0 & 0.1 & 0.323 \\
Respiration rate $\left(\mathrm{bpm}^{4}\right)$ & 82 & 83 & 2 & 0.548 \\
Milk yield change $(\%)$ & -11.4 & -13.7 & 3.3 & 0.522 \\
DMI change $(\%)$ & 3.2 & 3.8 & 3.8 & 0.880 \\
\hline
\end{tabular}

${ }^{1}$ Cows on waterbeds with insulation underneath and no circulating water.

${ }^{2}$ Cows on waterbeds with no insulation (i.e., waterbed placed directly on a concrete stall) and no circulating water.

${ }^{3} P$-value from a $t$-test.

${ }^{4}$ Breaths per minute.

the sprinkling schedule followed for the temperature, humidity, and airflow conditions in our experiment was $1 \mathrm{~min}$ on followed by $15 \mathrm{~min}$ off and using 1 nozzle per cow. The calculated water usage for $10 \mathrm{~h} / \mathrm{d}$ for a 120 -d cooling season for this system would be $3,650 \mathrm{~L} /$ cow per season. This water usage is comparable to that reported by Meyer et al. (2002), which was 4,010 L/ cow per $120 \mathrm{~d}$ but a fraction of the $15,500 \mathrm{~L} /$ cow per 120-d season reported by Frazzi et al. (2002). Although a benefit of conductive cooling systems is saving water by reusing water as a working fluid, the water usage of sprinkler systems is variable and depends on factors such as the design of the system and how many hours per day and days per season it is used. In this study, the water usage offset by the conductive cooling system was at the low end of sprinkler system water usage reported in the literature.

\section{CONCLUSIONS}

Conductive cooling effectively mitigated heat stress in lactating dairy cows. When cows were conductively cooled with $4.5^{\circ} \mathrm{C}$ water, Tre decreased by $1.0^{\circ} \mathrm{C}$, RR decreased by $18 \mathrm{bpm}$, milk yield increased by $5 \%$, and DMI increased by $14 \%$ compared with the control cows, which were exposed to the same environmental conditions but without conductive cooling. Rectal temperature was $0.3^{\circ} \mathrm{C}$ lower when cows were cooled with $4.5^{\circ} \mathrm{C}$ circulating water versus $10^{\circ} \mathrm{C}$ circulating water, but other variables did not show a significant difference between cooling water temperatures. The cooling system developed and used requires cooling the circulating water. Heat loss through waterbeds placed directly on a concrete surface showed no measureable effect in reducing the heat stress of the cows.

\section{ACKNOWLEDGMENTS}

This project was funded by the New York State Energy Development Authority (NYSERDA, Albany, NY) under agreement \#28264. The project was also funded in part by the USDA/Hatch (Washington, DC) funds as part of the W-273 Regional Project through Cornell University and the National Science Foundation Graduate Research Fellowship Program (NSF GRFP, Washington, DC) under grant \#DGE-1144153. The authors thank Curt Gooch for his role as a coadviser on the project, Timothy Shelford for his help with instrumentation, and Francoise Vermeylen for her statistical consulting (all at Cornell University, Ithaca, NY). Thanks also to Anna Schatz, Angela Cai, Doug Caveney, and Deborah Higgins from the Biological and Environmental Engineering department (Cornell University) as well as the staff at Large Animal Research and Teaching Unit (Cornell University) for their assistance with the research.

\section{REFERENCES}

Armstrong, D. V. 1994. Heat stress interaction with shade and cooling. J. Dairy Sci. 77:2044-2050.

Bastian, K. R., K. G. Gebremedhin, and N. R. Scott. 2003. Finite difference model to determine conduction heat loss to a water-filled mattress for dairy cows. Trans. ASAE 46:773-780.

Bernabucci, U., S. Biffani, L. Buggiotti, A. Vitali, N. Lacetera, and A. Nardone. 2014. The effects of heat stress in Italian Holstein dairy cattle. J. Dairy Sci. 97:471-486.

Collier, R. J., G. E. Dahl, and M. J. VanBaale. 2006. Major advances associated with environmental effects on dairy cattle. J. Dairy Sci. 89:1244-1253

Cook, N. B., R. L. Mentink, T. B. Bennet, and K. Burgi. 2007. The effect of heat stress and lameness on time budgets of lactating dairy cows. J. Dairy Sci. 90:1674-1682.

Crescio, M. I., F. Forastiere, C. Maurella, F. Ingravalle, and G. Ru. 2010. Heat-related mortality in dairy cattle: A case crossover study. Prev. Vet. Med. 97:191-197.

Dikmen, S., and P. J. Hansen. 2009. Is the temperature-humidity index the best indicator of heat stress in lactating dairy cows in a subtropical environment? J. Dairy Sci. 92:109-116.

Frazzi, E., L. Calamari, and F. Calegari. 2002. Productive response of dairy cows to different barn cooling systems. Trans. ASAE 45:395-405.

Gebremedhin, K. G., P. E. Hillman, C. N. Lee, R. J. Collier, S. T Willard, J. D. Arthington, and T. M. Brown-Barndl. 2008. Sweating rates of dairy cows and beef heifers in hot conditions. Trans. ASABE 51:2167-2178.

Hahn, G. L., J. D. Sikes, M. D. Shanklin, and H. D. Johnson. 1969 Dairy cow responses to summer air-conditioning as evaluated by switchback experimental design. Trans. ASAE 12:202-204., 208.

Igono, M. O., H. D. Johnson, B. J. Steevens, G. F. Krause, and M. D Shanklin. 1987. Physiological, productive, and economic benefits 
of shade, spray, and fan systems versus shade for Holstein cows during summer heat. J. Dairy Sci. 70:1069-1079.

Liu, D.-Y., S.-J. He, S.-Q. Liu, Y.-G. Tang, E.-H. Jin, H.-L. Chen, S.H. Li, and L.-T. Zhong. 2014. Daidzein enhances immune function in late lactation cows under heat stress. Anim. Sci. J. 85:85-89.

Merck Veterinary Manual. 2012. Reference guide: Normal rectal temperature ranges. Accessed May 28, 2015. www.merckvetmanual. $\mathrm{com} / \mathrm{mvm} /$ appendixes/reference_guides/normal_rectal_temperature_ranges.html.

Meyer, M. J., J. F. Smith, J. P. Harner, J. E. Shirley, E. C. Titgemeyer, and M. J. Brouk. 2002. Performance of lactating dairy cattle in three different cooling systems. Appl. Eng. Agric. 18:341-345.

Norman, H. D., R. H. Miller, J. R. Wright, J. L. Hutchinson, and K. M. Olson. 2012. Factors associated with frequency of abortions recorded through Dairy Herd Improvement test plans. J. Dairy Sci. 95:4074-4084.

Ortiz, X. A., J. F. Smith, F. Rojano, C. Y. Choi, J. Bruer, T. Steele, N. Schuring, J. Allen, and R. J. Collier. 2015. Evaluation of conductive cooling of lactating dairy cows under controlled environmental conditions. J. Dairy Sci. 98:1759-1771.

Ravagnolo, O., I. Misztal, and G. Hoogenboom. 2000. Genetic component of heat stress in dairy cattle, development of heat index function. J. Dairy Sci. 83:2120-2125.

Rhoads, M. L., J. W. Kim, R. J. Collier, B. A. Crooker, Y. R. Boisclair, L. H. Baumgard, and R. P. Rhoads. 2010. Effects of heat stress and nutrition on lactating Holstein cows: II. Aspects of hepatic growth hormone responsiveness. J. Dairy Sci. 93:170-179.

Spiers, D. E., J. N. Spain, J. D. Sampson, and R. P. Rhoads. 2004. Use of physiological parameters to predict milk yield and feed intake in heat-stressed dairy cows. J. Therm. Biol. 29:759-764.

St-Pierre, N.R., B. Cobanov, and G. Schnitkey. 2003. Economic losses from heat stress by US livestock industries. J. Dairy Sci. 86(E. Suppl.):E52-E77.

Stull, C. L., L. L. McV. Messam, C. A. Collar, N. G. Peterson, A. R Castillo, B. A. Reed, K. L. Anderson, and W. R. VerBoort. 2008. Precipitation and temperature effects on mortality and lactation parameters of dairy cattle in California. J. Dairy Sci. 91:4579 4591.

Suthar, V., O. Burfeind, S. Bonk, R. Voigtsberger, C. Keane, and W. Heuwieser. 2012. Factors associated with body temperature of healthy Holstein dairy cows during the first 10 days in milk. J. Dairy Res. 79:135-142.

USDA. 2006. Milk production, disposition, and income 2005 summary. Accessed Aug. 24, 2014. http://www.ams.usda.gov/AMSv1.0/getf ile?dDocName=STELPRDC5050722.
USDA. 2010. Facility characteristics and cow comfort on U.S. dairy operations, 2007. \#524.1010. USDA-APHIS-VS, CEAH, Fort Collins, $\mathrm{CO}$.

USDA. 2014. Milk production, disposition, and income 2013 summary. Accessed Jun. 25, 2014. http://usda.mannlib.cornell.edu/usda/ current/MilkProdDi/MilkProdDi-04-29-2014.txt.

West, J. W. 2003. Effects of heat-stress on production in dairy cattle. J. Dairy Sci. 86:2131-2144.

West, J. W., B. G. Mullinix, and J. K. Bernard. 2003. Effects of hot, humid weather on milk temperature, dry matter intake, and milk yield of lactating dairy cows. J. Dairy Sci. 86:232-242.

Zimbelman, R. B., R. P. Rhoads, M. L. Rhoads, G. C. Duff, L. H. Baumgard, and R. J. Collier. 2009. A re-evaluation of the impact of temperature humidity index (THI) and black globe humidity index (BGHI) on milk production in high producing dairy cows. Pages 158-169 in Proc. Southwest Nutrition and Management Conf. University of Arizona, Tucson.

\section{APPENDIX}

The cooling level $\times$ thermal environment interaction terms were not significant, but some of the comparisons within these terms were statistically significant (Table A1). Models for all 4 responses included the random effects of the variations between cows (Cow ID) and Cow ID nested within treatment, as well as the fixed effects of cooling level (control/no cooling, $10^{\circ} \mathrm{C}$ circulating water, and $4.5^{\circ} \mathrm{C}$ circulating water), thermal environment (thermal environment 1 with average THI of 79.0 or thermal environment 2 with average THI of 80.7), and the cooling level $\times$ thermal environment interaction. Models for milk yield and DMI $(\mathrm{kg} / \mathrm{cow}$ per day) included the baseline values from treatment 1 as a linear co-variant, and models for Tre and RR included the baseline values from treatment 1 as well as the measurements from each corresponding morning at $0730 \mathrm{~h}$.

Table A1. Comparison of conductive cooling treatments showing LSM, SE, and $P$-values of different cooling treatments for the 2 room temperatures

\begin{tabular}{|c|c|c|c|c|c|c|c|c|}
\hline $\mathrm{THI}^{2}$ & Variable & Control & $10^{\circ} \mathrm{C}$ & $4.5^{\circ} \mathrm{C}$ & $\mathrm{SE}$ & \multicolumn{3}{|c|}{$P$-value ${ }^{3}$} \\
\hline \multirow{3}{*}{$80.7 \pm 0.9$} & Respiration rate (bpm) & 85 & 69 & 63 & 2.7 & $<0.001$ & $<0.001$ & 0.063 \\
\hline & Milk yield change (\%) & -16.5 & -9.0 & -5.8 & 3.9 & 0.112 & 0.039 & 0.513 \\
\hline & Milk yield ( $\mathrm{kg} /$ cow per day) & 28.8 & 31.0 & 32.3 & 1.3 & 0.145 & 0.038 & 0.415 \\
\hline \multirow{5}{*}{$79.0 \pm 1.0$} & Respiration rate (bpm) & 80 & 65 & 63 & 2.2 & $<0.001$ & $<0.001$ & 0.377 \\
\hline & Milk yield change (\%) & -6.7 & -0.9 & -1.8 & 3.4 & 0.187 & 0.109 & 0.835 \\
\hline & Milk yield (kg/cow per day) & 31.8 & 34.1 & 33.3 & 1.1 & 0.119 & 0.129 & 0.598 \\
\hline & DMI change $(\%)$ & 13.8 & 20.6 & 24.5 & 4.2 & 0.097 & 0.002 & 0.365 \\
\hline & DMI (kg/cow per day) & 20.9 & 22.3 & 22.9 & 0.7 & 0.090 & 0.003 & 0.471 \\
\hline
\end{tabular}

${ }^{1}$ Data were collected on 4 cooled cows and 4 control (not cooled) cows for at least 1 wk for each of the 4 combinations of daytime temperaturehumidity index (THI: $80.7 \pm 0.9$ and $79.0 \pm 1.0)$ and cooling water temperature $\left(10^{\circ} \mathrm{C}\right.$ and $\left.4.5^{\circ} \mathrm{C}\right)$.

${ }^{2} \mathrm{THI}=(1.8 \times \mathrm{db}+32)-[(0.55-0.0055 \times \% \mathrm{RH}) \times(1.8 \times \mathrm{db}-26.8)]$, where $\mathrm{db}$ is dry bulb temperature $\left({ }^{\circ} \mathrm{C}\right)$ and $\% \mathrm{RH}$ is relative humidity. ${ }^{3} P$-values from $t$-tests. 